\title{
In de spreekkamer is opzoekkennis belangrijker dan parate kennis*
}

\section{A.J.J.A. Scherpbier}

Parate kennis is altijd belangrijk geweest in de spreekkamer en zal dat ook altijd blijven. Toch verandert er veel in de geneeskunde: zo is er veel nieuwe kennis, worden de kosten steeds belangrijker en weegt de effectiviteit steeds zwaarder. Een belangrijke vraag is dan: welke parate kennis moet een arts hebben om een probleem van een patiënt lege artis te kunnen oplossen en wat kan de arts ook, of misschien zelfs beter, opzoeken?

Deze vraag kunnen wij alleen beantwoorden als wij weten wat er in de spreekkamer gebeurt en waar dit toe leidt. Wij leveren een goede kwaliteit zorg, maar weten ook dat nieuwe kennis in de praktijk niet of nauwelijks wordt geïmplementeerd. ${ }^{1}$ De verrichte diagnostiek is niet altijd adequaat en kosteneffectief. Ook de farmacotherapie is niet altijd optimaal: kosten en ongewenste bijwerkingen zijn vaak terugkerende items in de media. Kortom, in de praktijk hebben artsen kennelijk niet altijd de recentste en beste kennis paraat. Studies bevestigen dat de competenties van artsen enige tijd na het afstuderen afnemen. ${ }^{2}$

Groeiende kennis en snelle veranderingen maken het ook feitelijk onmogelijk en daarmee niet meer van deze tijd - om steeds alles paraat te hebben. Dus is opzoekkennis in de spreekkamer van groot belang. Nadruk op parate kennis is wel begrijpelijk, omdat velen nog de opvatting huldigen dat expertise blijkt uit het tonen van veel parate kennis. Terecht wordt een expert echter tegenwoordig beschreven als "iemand die kennis doelmatig en verstandig weet te vinden en die conceptuele verbanden kan leggen tussen ogenschijnlijk niet-gerelateerde gebieden". ${ }^{3}$

Om iets te gaan opzoeken moet de arts eerst beseffen dat het hem of haar aan bepaalde kennis over recente ontwikkelingen ontbreekt. Dat is een attitude die niet iedereen van nature bezit. Bovendien verwachten patiënten soms ook nog dat de dokter alles weet, al is dat snel aan het veranderen. Daarnaast blijkt de geschikte informatie soms moeilijk te vinden. ${ }^{4}$ Informatie uit bijvoorbeeld een grote trial kan niet zonder meer vertaald worden naar de individuele patiënt. Opzoeken kost bovendien tijd. Kortom, wij zullen artsen moeten helpen bij het zoeken en beoordelen van de juiste informatie. Dat kan op verschillende manieren. Meer aandacht in de opleidingen voor het leren inschatten van de eigen sterke en zwakke punten en het leren opzoeken en beoordelen van nieuwe informatie. En na de opleiding meer aandacht voor het ontwikkelen van effectieve hulpmiddelen om bij te blijven. Ook moeten wij werken aan een cultuur waarin het normaal is om bij te blijven. Meer onderzoek naar expertiseontwikkeling na de vervolgopleiding is belangrijk voor de kwaliteit van zorg, evenals het vertalen in praktische suggesties van wat wij hierover nu al weten. ${ }^{2}$ In een goede cultuur kunnen moderne hulpmiddelen, zoals palmtopcomputers, van pas komen

\footnotetext{
* Dit artikel verschijnt ook in het Nederlands Tijdschrift voor Geneeskunde.
} 
bij het bijhouden en het paraat hebben van recente kennis.

Parate kennis is belangrijk: de arts moet immers het probleem van de patiënt kunnen analyseren. Maar toch, als ik bij een arts ben, heb ik liever dat hij iets opzoekt dan dat hij alles paraat denkt te (moeten) hebben.

\section{Literatuur}

1. Gezondheidsraad. Van implementeren naar leren: het belang van tweerichtingsverkeer tussen praktijk en wetenschap in de gezondheidszorg. Den Haag: Gezondheidsraad; 2000. Publicatienr. 2000/18.
2. Ericsson KA. Deliberate practice and the acquisition and maintenance of expert performance in medicine and related domains. Acad Med 2004;79(10 Suppl): S70-81.

3. Fraser SW, Greenhalgh T. Coping with complexity: educating for capability. BMJ 2001;323:799-803.

4. Ely JW, Osheroff A, Ebell MH, Chambliss ML, Vinson DC, Stevermer JJ, et al. Obstacles to answering doctors' questions about patient care with evidence: qualitative study. BMJ 2002;324:710.

De auteur:

Prof. dr. A.J.J.A. Scherpbier is arts-opleidingsdirecteur.

Correspondentieadres:

Prof. dr. A.J.J.A. Scherpbier, Universiteit Maastricht, Onderwijsinstituut Geneeskunde, Postbus 616, 6200 MD Maastricht.

\section{Summary}

In the consultation room, it is better to have a doctor that looks something up than one who thinks that he has (or should have) everything at his fingertips. Doctors require ready knowledge, but the rapid changes make it impossible to keep all knowledge at the ready. Training courses must pay attention to the retrieval, assessment and maintenance of (new) professional knowledge. A positive attitude and helpful aids are essential here. (Scherpbier AJJA. In the consultation room, knowledge that one can look up is more important than ready knowledge. Dutch Journal of Medical Education 2006;25(1):43-44.) 